\title{
POLICEMEN'S PERCEPTION OF THEIR EXPERIENCE WORKING IN A HIGH-RISK AREA
}

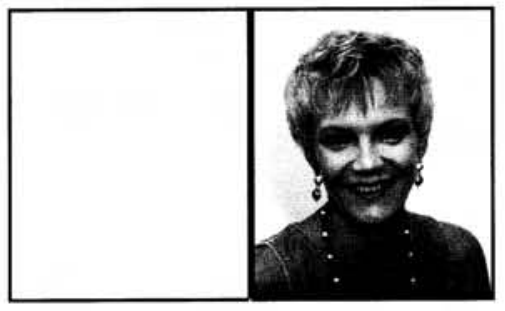

\author{
Leigh Robinson, M.Cur (Psychiatric Nursing) \\ Rand Afrikaans University \\ Antoinette Gmeiner, D.Cur (Psychiatric Nursing) \\ Senior Lecturer \\ Department of Nursing Science \\ Rand Afrikaans University
}

\begin{abstract}
In this article the results of research, undertaken to explore and describe how single male policemen belonging to one of three identified units experience working in a specific high-risk metropolitan area in Gauteng, are discussed. A significant number of members of the police service were found to be admitted to a certain psychiatric clinic in Gauteng for various psychiatric and psychological reasons. There seemed to be a need for members to be invested in by psychiatric nurse specialists and other health professionals. However, the story needed to be told by the policemen themselves, rather than from a medical/diagnostic perspective. From this the research question arose: "How do single male policemen belonging to one of three identified units experience working in a specific high-risk metropolitan area in Gauteng?" A qualitative, descriptive, exploratory and contextual design was utilized. In-depth semi-structured phenomenological interviews were used to gather data concerning their experience working in the identified high-risk area. To ensure trustworthiness, Guba's model (in Krefting 1991:214215) was implemented. Through data analysis, five categories were identified: external factors are viewed as obstacles in the work of policemen; the experience of physical exhaustion and discomfort; policemen's perception of their experience of crime and violence in the identified high-risk area; conflict within and disintegration of their relationships; emotions experienced and defense mechanisms used by policemen.
\end{abstract}

This research was undertaken with the hope that it would help to break the chains of silence that bind policemen.

\section{OPSOMMING}

In hierdie artikel word die resultate bespreek om die ervaring van alleenlopende manlike polisiebeamptes, wat aan een van die drie geïdentifiseerde eenhede van 'n spesifieke hö̈-risiko metropolitaanse area in Gauteng behoort, te verken en te beskryf. Daar is gevind dat ' $n$ aansienlike aantal lede van die polisiediens in 'n sekere psigiatriese kliniek in Gauteng opgeneem is vir verskeie psigiatriese en psigologiese redes. Dit blyk dat daar ' $n$ groot behoefte is dat die psigiatriese verpleegspesialiste en professionele gesondheidspersoneel in dié lede investeer. Hierdie ervarings moes egter deur polisiebeamptes self weergegee word, eerder as vanuit ' $n$ medieseldiagnostiese-perspektief. Die volgende navorsingsvraag het ontstaan: "Hoe ervaar alleenlopende manlike polisiebeamptes, wat aan een van die drie geïdentifiseerde eenhede behoort, hulle werk in 'n spesifieke hö̈-risiko metropolitaanse area in Gauteng?" 'n Kwalitatiewe, verkennende, beskrywende en kontekstuele ontwerp is gebruik. Daar is van in-diepte, semi-gestruktureerde fenomenologiese onderhoude gebruik gemaak om data in te samel. Om die vertrouenswaardigheid te verseker is Guba se model toegepas (in Krefting 1991:214215). Deur data-analise is vyf kategorië gë̈dentifiseer, naamlik: eksterne faktore word as struikelblokke in polisiewerk beskou; die ervaring van fisiese uitputting en ongemak; polisiebeamptes se persepsie van hul ervarings van misdaad en geweld in ' $n$ gë̈dentifiseerde hö̈-risiko area; konflik in en disintegrasie van hul verhoudings; emosionele ondervindings en verdedigingsmeganismes wat deur polisiebeamptes gebruik word.

Hierdie navorsing was daarop gemik om die bande van stilswye waardeur polisiebeamptes gebind word, te verbreek.

\section{BACKGROUND AND RATIONALE}

In April 1994, the first democratic general election was held which brought about a change for the South African people. The dramatic changes in government changed the face of policing from an autocratic force to a community-based service. Since the election three years ago, the battle-lines between political and criminal violence have been blurred, leav- ing many victims in its wake, including policemen. Crime is on the rampage. One need only to page through any of our newspapers to acquire some idea of its violent nature which ranges from rape, robbery, theft, illegal possession of firearms, murder, assault, house-breaking, hijacking and commercial theft, to name but a few (Reeves, 1997:13). 
Some of the myriad of difficulties faced by South African policemen today have been widely published, with the voices of politicians debating issues concerning the police, described by a previous National Party leader as being in a "Parlous and demoralised state" (Ensor, 1996:2). These issues include amongst others the low salaries policemen receive, overwork (Ensor, 1996:2), inadequate information and evaluation-gathering systems consequently providing the police with inaccurate statistics (Friedman, 1996:4). In addition, many crimes go unreported, exacerbating the problem further (Friedman, 1996:4). Difficulties in the relationship between the Police and the Justice Department create further problems, with accusations being made that the police provide inadequate information for decisions to be made concerning criminals, and that the courts grant dangerous criminals bail (SABC: 1996). This leaves the member feeling that the policeman is 'damned if he does' and 'damned if he doesn't' (SABC:1996). The much publicised issue of corruption, described as the 'enemy within' poses a threat to both the policeman and the civilian, with those involved having access to information which is used for their own gain (Anon., 1996:12).

Despite this, we are encouraged to remain hopeful. The voices of politicians, reporters and other community leaders encourage, support and give assurance that the colourful visions of the rainbow nation will remain intact with proposed strategies, plans and statistics. However, the reality of being a policeman on the streets of South Africa is often lost within the speeches and statements, as each day it is their task to protect that vision, our vision, against crime and violence.

The criminally motivated killing of police for their service pistols and other equipment, rather than the politically motivated killings of the past (August, 1994:8) and the fact that policemen are often involved in dangerous and lifethreatening situations (Marks, 1995:2), lead to policemen viewing the community as a threat (August, 1994:8). Thus, the prospect of their own death and those of their colleagues are acknowledged by the members in the privacy of their own thoughts (Kruger, 1996:11), with the death of colleagues throwing them into their 'own private hell' (Anon., 1996:18).

Other sources of stress include little recognition and feedback from management (Marks, 1995:5), the demands of shiftwork and life and death decisions (Huisamen, 1993:19), the constitution, viewed by policemen as assisting the criminal more than the community (SABC:1996) poses an additional stressor, together with personality types, with Type A being more susceptible (Anon., 1996:7), perceptions of stress (Anon., 1996:13), social situations (Huisamen, 1993:18), interpersonal relationships (Anon., 1993:2) and the existence and availability of support systems (Anon., 1993:12). Throughout this, policemen maintain a 'cowboys don't cry' attitude (Huisamen, 1993:19) and do not make use of available psychological services due to negative connotations that they have (Kruger, 1996:11). Silence in family relationships is maintained, believing that it prevents 'unnecessary worrying' of the policemen's family members, with things rather being spoken about with police 'buddies' over a few drinks (Kruger, 1996:11). Together with the above-mentioned factors and considering recent suicide statistics it is of the utmost importance that policemen tell their story, before it is silenced by their own or another's bullet, or slurred by alcohol and drugs, because policemen might not be the only casualty - we might be too.

\section{PROBLEMSTATEMENT ANDOBJECTIVES}

To state the research problem, the following narrative description was used:

$\mathrm{He}$ joined the service in 1991 at nineteen and trained as a police officer, was given a gun and a uniform, and instructed to implement what he had been taught. These were inadequate in preparing him for the cruelties he was to witness and the emotions experienced in a riot situation, with the loss of a friend and colleague, or seeing a young girl necklaced. Crime and violence impacted on every dimension of his life, leaving him a "quite bitter person, emotionless and distrustful". His wife left, not being able to be married to a cop. "This is what violence and crime has done to me...." . His friends abused alcohol and drugs as coping mechanisms, or took their own lives, due to the exposure to crime and violence. Staying positive is always something he has managed to do, but this too has become difficult in the face of an escalating crime rate and management problems. However, he says that: "the beat goes on, the work must be done."

Based on this story the following research questions arose: "How do single male policemen, belonging to one of three identified units, experience working in a specific high-risk metropolitan area in Gauteng?"

The objectives of this study are to explore and describe how single male policemen belonging to one of three identified units experience working in a specific high-risk metropolitan area in Gauteng.

\section{RESEARCH DESIGN AND METHOD}

A qualitative, exploratory, descriptive and contextual design was utilized (Mouton \& Marais, 1994:43-44,51). An in-depth, semi-structured phenomenological interview (Burns \& Grove, 1993:578 - 581) was used to collect data from the policemen who met the sample criteria of this research regarding their experience working in a specific high-risk metropolitan area in Gauteng.

The method was used in an effort to explore and describe the policemen's experience from their perspective and orientation, rather than from that of the researcher.

\section{SAMPLE}

The target population identified for this research includes all single male policemen belonging to one of three identified units working in a specific high-risk metropolitan area in Gauteng. Purposive sampling was used to achieve saturation of data and involved the conscious selection by (myself as) the researcher of policemen to be included in the study (Burns \& Grove, 1993:246), in order to meet the requirements of the sampling criteria.

\section{MEASURES FOR ENSURING TRUSTWOR- THINESS}

Guba's model (in Krefting, 1991:214-215) was used to ensure trustworthiness in this research.

The four criteria used to ensure trustworthiness were: truthvalue, applicability, consistency and neutrality (Krefting, 
1991:214-222). Using the strategy of credibility, and applicability by applying the strategy of transferability ensured truth-value, consistency through the use of the strategy dependability, and neutrality using the strategy of confirmability.

Table 1 summarizes the strategies to ensure trustworthiness.

\section{Table 1: $\quad$ Strategies to ensure trustworthiness}

\begin{tabular}{|c|c|c|}
\hline Strategy & Criteria & Applicability \\
\hline \multirow[t]{6}{*}{ Credibility } & Prolonged engagement & $\begin{array}{l}\text { Contact at identified police station. Initially spent time with policeman working in the } \\
\text { area identified in this study to build rapport. Allow time for participant to verbalize } \\
\text { experiences. }\end{array}$ \\
\hline & Reflexibility & Taking field notes \\
\hline & Member checking & $\begin{array}{l}\text { Follow-up interviews with participant policemen concerning findings and proposed } \\
\text { guidelines. A literature control will be conducted using findings of similar studies } \\
\text { done in an about the South African Police Service as well as those with information } \\
\text { about trauma and its effects. Discussion with colleagues will also take place as a } \\
\text { form of member checking. }\end{array}$ \\
\hline & Peer examination & $\begin{array}{l}\text { The services of a colleague also conducting research in the South African Police } \\
\text { Service will be acquired to confirm some of the findings of this research. }\end{array}$ \\
\hline & Authority of research & $\begin{array}{l}\text { The researcher has undergone previous training in research methodology. The re- } \\
\text { search will be supervised by a person who has a doctorate in psychiatric nursing and } \\
\text { who also has extensive experience in conducting qualitative research. }\end{array}$ \\
\hline & Structural coherence & $\begin{array}{l}\text { The focus will be on the experience of the policemen belonging to one of three iden- } \\
\text { tified units working in a specific high-risk metropolitan area in Gauteng. Results will } \\
\text { be reflected within Nursing for the Whole Person Theory. }\end{array}$ \\
\hline \multirow[t]{2}{*}{ Transferability } & Nominated sample & The sampling method will be purposive with no prior selection. \\
\hline & Dense description & Complete description of design, methodology and literature control to maintain transparency \\
\hline \multirow[t]{4}{*}{ Dependability } & Audit trail & Keeping personal logs and field notes. \\
\hline & Dense description & Research methodology fully described. \\
\hline & Peer examination & $\begin{array}{l}\text { Independent checking by a colleague who will play the role of "devil's advocate", and } \\
\text { supervision by other nurses with experience in the field of qualitative research. }\end{array}$ \\
\hline & Code-recode procedure & Consensus discussion between researcher and independent coder. \\
\hline \multirow[t]{2}{*}{ Conformability } & Audit trail & As discussed. \\
\hline & Reflexibility & As discussed. \\
\hline
\end{tabular}

* Adapted with permission from a table in (Poggenpoel \& Muller, 1996: 9).

\section{DATA COLLECTION}

Members who met the sampling criteria were interviewed at the police station at various pre-arranged dates and times. Data was collected by means of nine in-depth semi-structured phenomenological interviews which were recorded with the use of a dictaphone and transcribed verbatim (Burns \& Grove, 1993:578-581). One of these interviews was the pilot study, which was conducted to identify any research problems. Field notes were also taken.
The question was posed:

"As a policeman, how do you experience working in this high-risk area?" 


\section{DATA ANALYSIS}

Data was analysed by two coders independent of each other. The first was myself as the researcher of the study, the other an advanced psychiatric nurse practitioner with a Ph.D. and experience in qualitative research. Data was analysed using the descriptive analysis method suggested by Tesch (in Creswell, 1994:155). The steps that were followed in the method were:

- All of the transcriptions of the policemen's experience working in the identified high-risk area, were read through, whilst ideas were jotted down in the margin of the transcription.

- Categories and themes of the policemen's experience working in the identified high-risk area were formulated.

- Following this, consensus discussions between myself as researcher and the independent coder were held.

\begin{tabular}{|c|c|c|}
\hline Category & Theme & \\
\hline $\begin{array}{l}\text { "Obstacles Causes": } \\
\text { 3.1.1External factors are } \\
\text { viewed as obstacles in } \\
\text { the work of policemen. }\end{array}$ & $\begin{array}{l}\text { 3.1.1.1 Morale of policemen is described as low due to } \\
\text { various external factors in the South African Police Service, } \\
\text { both on a social and national level, contributing to the } \\
\text { difficulty of police work. }\end{array}$ & $\begin{array}{l}\text { A deteriorating physical environment } \\
\text { is not conducive to a healthy work- } \\
\text { ing environment. } \\
\text { Workload is large. } \\
\text { Shortage of staff. } \\
\text { - Judicial system inadequate. } \\
\text { Resources poor/scarce. } \\
\text { - Training poor/inadequate. } \\
\text { - Salaries poor. }\end{array}$ \\
\hline $\begin{array}{l}\quad \text { "Deadly-tired": } \\
\text { 3.1.2 Policemen experience } \\
\text { physical exhaustion and dis- } \\
\text { comfort. }\end{array}$ & $\begin{array}{l}\text { 3.1.2.1 The policemen experience physical exhaustion } \\
\text { and discomfort as well as cognitive and behavioural } \\
\text { changes related to long working hours, shortage of } \\
\text { staff and a large workload. }\end{array}$ & \\
\hline $\begin{array}{l}\text { "Soldier-on vio- } \\
\text { lence": } \\
\text { 3.1.3 The policemen's percep- } \\
\text { tion of their experience of crime } \\
\text { and violence in the identified } \\
\text { high-riskarea. }\end{array}$ & $\begin{array}{l}\text { 3.1.3.1 Policemen experience crime in the identified highrisk } \\
\text { area in which they workas persistent, pervasive and ofa } \\
\text { unique quality due to the nature of the crimes committed } \\
\text { and the frequency with which they occur. } \\
\text { 3.1.3.2 The policemen redefine the self and the world } \\
\text { they live in, due to meaning being questioned when } \\
\text { exposed to violence and crime in their work situation. } \\
\text { 3.1.3.3 The policemen reflect on an uncertain future, their } \\
\text { mortality and beliefs about death and dying as being } \\
\text { 'part of everyday life', due to their exposure to the } \\
\text { death of members of the community and their colleagues } \\
\text { as a result of crime and violence. } \\
\text { 3.1.3.4 The policemen experience their work as both challeng- } \\
\text { ing and stimulating opportunities for learning and per- } \\
\text { sonal growth due to the diversity of the community they } \\
\text { serveand their exposure to a variety of experiences in the } \\
\text { identified area. }\end{array}$ & $\begin{array}{l}\text { The policemen experience suicidal ideas } \\
\text { and may attempt suicide due to feelings } \\
\text { of being trapped and overwhelmed, cre- } \\
\text { ating aneed for escape. }\end{array}$ \\
\hline $\begin{array}{l}\text { "Silent knights": } \\
\text { 3.1.4 Conflict within and disin- } \\
\text { tegration of the policemen's re- } \\
\text { lationships. } \\
\text { The policemen's perception of } \\
\text { their experience of relationships } \\
\text { with colleagues. } \\
\text { The policemen's perception of } \\
\text { their of relationships with supe- } \\
\text { riors (who represent the manage- } \\
\text { ment of the service). }\end{array}$ & $\begin{array}{l}\text { 3.1.4.1 The police "bond" is viewed as being exclusive } \\
\text { and supportive; however, communication is maintained } \\
\text { on a superficial level due to existing beliefs of being a } \\
\text { failure if feelings are voiced or discussed. } \\
\text { 3.1.4.2 Policemen experience support from, and com- } \\
\text { munication with, management as inadequate due } \\
\text { to their perceptions of management being unavailable, } \\
\text { uninvolved at grass roots level, experiences of being } \\
\text { discriminated against and the traditional hierarchical } \\
\text { nature of the system. }\end{array}$ & \\
\hline
\end{tabular}

The results of the research were discussed in the light of relevant literature and information obtained from similar research, to verify the results and to highlight similarities and differences between this research and others conducted in the past.

\section{RESULTS AND DISCUSSION OF RESULTS}

Results of this research are summarized in Table 2.

Table 2 : An overview of major categories and themes of policemen belonging to one of three identified units and their description of their experience working in a specific high-risk metropolitan area in Gauteng. 
The policemen's perception of their experience of relationships with the community they serve. The policemen's perception of their experience in respect of personal relationships.

3.1.4.3 Poor relationships exist between the police and the community it serves due to the legacy of the apartheid era, which is evidenced by the community's distrustful attitude towards the police and the police feeling 'cut-off' from the community.

3.1.4.4 Conflict in and disintegration of personal relationships related to work circumstances, attitudes and roles assumed.

3.1.5.1 The policemen experience feelings of anger, frustration and resentment related to the violent nature of crime, external factors and beliefs about, and occurrences in professional and personal relationships.

"Buried alive"

3.1.5 Emotions, experiences and defense mechanisms used by policemen to cope with emotions in an effort to maintain emotional equilibrium.
3.1.5.2 The policemen experience fear as a result of the nature of their work, dealing with crime and violence, which creates a need for self-protection.

3.1.5.3 The policemen experience feelings of pain and sadness related to situations and events where they perceive loss having occurred.

3.1.5.4 The policemen experience feelings of guilt related to the taking of another person's life.

3.1.5.5 Powerlessness, helplessness and disillusionment related to persistence of crime and violence and the existence of a continuous threat to their own lives.

3.1.5.6 The policemen experience feelings of loneliness related to isolating behaviour in relationships with friends and colleagues.
- Use of rationalisation, intellectualisation, displacement and passive aggression due to feelings of anger, frustration and resentment in an effort to maintain emotional equilibrium.

- Rationalisation and humour used as a defense mechanism against feelings of fear in an effort to maintain emotional equilibrium.

- Intellectualisation, rationalisation and dissociation used as defense mechanisms against feelings of pain and sadness in an effort to maintain emotional equilibrium.

- Rationalisation used as a defense mechanism against guilt feelings in an effort to maintain emotional equilibrium.

- Secondary repression is used as a defense mechanismagainst feelings of powerlessness, hopelessness and disillusionment in an effort to maintain emotional equilibrium.

- Denial and rationalisation are used as defense against feelings of loneliness in an effort to maintain emotional equilibrium.
The first category dealt with external factors, which are viewed as obstacles in their work contributing to both the difficulty of policing, and the existing low morale of the police. These include a deteriorating physical environment, which was described as "vervallend" by one participant and the use of personal notes as a form of literature control, and these described how the "paint peeled off the discoloured walls, while a strong smell of urine filtered into the room together with the strains of traffic...".

A heavy workload and staff shortages were identified with one participant saying: "Jirr, it's too much work", while another described the effects of staff shortages: "ag ons sukkel, die moraal is laag en niemand wil rêrig hier werk nie". Literature supports this, reporting that "Johannesburg suburbs are short of 1753 policemen” (SAPA, 1997:7).

The judicial system is viewed as inadequate with one policeman describing his experience concerning this as follows: "Dit pla my, want jy werk jou dinges af ... en dan sê die hof, 'Jammer daar is nie ' $n$ saak nie'". A television documentary shown last year commented on the difficulties existing between the police service and judicial system (SABC:1996).

Resources within the system are scarce and training inadequate, with members complaining that: "we don't have enough transport you know", while another reported that: "at college I was not taught how to check a stolen car". Numerous newspaper articles highlighted the problem of insufficient resources reporting, "So much crime, so few vehicles", while criticisms have been levelled at the inadequacy of both content and process of training (Levin, Ngubeni \& Simpson, 1994:4).

Poor salaries were mentioned by all participants with one describing it as: "Policemen are getting killed and are getting paid nothing for this work". This issue has been widely published, with one headline reporting that there seems to be a need for "better salaries" (SAPA, 1997:9).

The second category reflects the policeman's experience of physical exhaustion and discomfort as well as cognitive and behavioral changes related to long working hours, a heavy workload and staff shortages. These reflected in the following quote: "Jy is heeltemal uitgeput, jy is moeg en jy kan nie konsentreer nie. Dan is ek beneuk". Marks (1995:5) confirmed this, describing police work as often being exhausting.

The third category describes policemen's perception of their experience of crime and violence in the identified high risk area, describing it as persistent, pervasive, and of a unique quality, related to the nature of the crimes committed, and the frequency with which they occur. The unique quality 
and crime's pervasiveness was reflected in the following quote: "Hades*, things happen here that don't happen anywhere else in the world ... "bam" shots go off ... it's a normal day". While its persistence was highlighted by the statement: "It happens here every single day, day in, day out, night in, night out". (* Not real name of area)

Hamber and Lewis (1997:3) described South Africa as having a culture of violence where violent crime and trauma are normative in our society. However, one respondent described crime and violence as: "not as risky as before", but did acknowledge its unpredictable nature saying: "anything can happen at any time". Speaking in the voice of the struggle, the story of some black policemen assumes a "not as bad as before theme". Thus, taking into consideration the history of the country, Marks (1995:3) said a large number of black officers experienced difficulties with promotion and discrimination in the past.

Policemen redefine the self and the world in which they live, due to meaning being questioned when exposed to crime and violence in their work. One viewed himself as inseparable from his environment, "you are part of it", and another viewed and approached the world in a hostile fashion saying: "You don't trust anybody ... hy sal jou vrek maak". Life in their world is viewed as meaningless. A participant related a story where a shop owner shot a customer in the head, and reflected that: "... life means nothing here". Hamber and Lewis (1997:9) supports this asserting that violence and trauma shatter healthy assumptions about the self and the world, while Shay (1996:53) said that a persistence of meaninglessness contaminates identity.

Due to exposure to death of members of the community and colleagues at the hands of crime, policemen reflect on an uncertain future, their mortality and beliefs about death as being part of "everyday life". The following indicates this: "He died on the scene, you just have to wait for your day ... you get it here every day, it is part of life". Hamber and Lewis (1997:9) supports this, stating that the basic and fundamental belief of personal invulnerability is shattered by trauma.

Suicidal ideas and past suicide attempts were also reported due to feelings of being trapped and overwhelmed, creating a need for escape. One participant described his experience of this as follows: "Selfmoord, ek het baie daaraan gedink, ek het dit ook probeer". It was reported that one hundred and ninety six officers had killed themselves since January 1995 (Anon., 1996:2).

Despite these negative perceptions, policemen also experience their work as challenging and stimulating, creating opportunities for learning and personal growth related to the diversity of the community they serve and an exposure to a variety of experiences in the identified high risk area. The policemen who participated in the study say: "Everyday is a different challenge", and that "you learn a lot of things ... and develop yourself as a person". A previous study conducted revealed a high level of dedication and enjoyment in the work, despite the high levels of stress and trauma they might experience (SAPA, 1997:9).

The fourth category describes the relationships of the policemen where they experience both conflict in and disintegration of relationships. With respect to relationships with colleagues, mention was made of the exclusive "bond" which, between policemen, is viewed as supportive; however, communication is maintained on a superficial level due to existing beliefs of being a failure if feelings are voiced or discussed. This "exclusive bond" was referred to as: “.... Daai band tussen polisiemanne ... hulle verstaan waaroor dit gaan." The participant then went on to describe communication saying: "Jy praat nie daaroor nie ... Jy wys nie jou emosies nie, want die oomblik wat jy dit wys voel jy asof jy " $n$ swakeling is". Marks (1995:3) referred to this "cowboy image" and its affects on relationships.

In terms of relationships with management/ superiors support and communication is viewed as inadequate, with management being perceived as unavailable and uninvolved at grass roots level. Experiences were related of being discriminated against, and the traditional hierarchical system also contributing to inadequate and ineffective communication channels. One participant described this saying, "they cannot come down to the people", while another experienced discrimination when the superintendent gave his car keys to a white officer. The participant reflected that, "obviously he does not want a black guy to drive his car". Another referred to the traditional hierarchical system as not allowing the opinions of lower-ranking officers to be heard saying, "dan het jy nie kans om te verduidelik nie". Marais and Rauch (1994:12) support this saying that the hierarchical nature contributes to ineffective and clumsy communication channels.

It has previously been mentioned that trauma shatters healthy assumptions about the self and world (Hamber \& Lewis, 1997:9), contributing to hostile and distrustful attitudes of policemen towards the world, influencing their relationship with the community which was found to be poor, due to the legacy of the apartheid era. This is evidenced by the community's mistrustful attitude towards the police, and the police feeling "cut-off" from them.

The following statements bear testimony to this, “... they treat you like dirt because you are part of the old regime," another said: "..they don't trust policemen", and one policeman reflected on being "cut off" saying, "We are not part of the community". Community policing forms part of a framework for the restructuring of the police force into a service (Mistry, 1997:41) and is viewed as a major factor in the healing of this relationship.

Concerning personal relationships, conflict and disintegration occur related to work circumstances, attitudes and roles assumed. The following statement reflects this disintegration: "My wife left me because she couldn't live with the stress of waiting for someone who knocks on the door and tells her I'm dead". The "exclusive bond" of the police service also contributes to the disintegration of relationships, and was described by one participant as follows: "Hulle kan nie verstaan nie ... hulle is nie deel van die groep van 'n polisieman nie ...". The influence of the policemen's attitudes on relationships is illustrated by the following: "I just don't care ... it rubs off on family life". The protective roles assumed by policemen create silence: "Ek vertel haar nie oor gevaarlike dinge nie ... ek wil haar nie ontstel nie", as well as their isolating behaviour evidenced by the following: "As ek by die huis kom moet hulle my net uitlos". Shay (1996:46) supports these findings saying that safe, nonviolent attachments can become virtually impossible. However, some policemen viewed their families as supportive saying that: "... my family understands me”, with no literature available to support this. 
The fifth category describes the emotions policemen experience and defence mechanisms used to cope with them in an effort to maintain emotional equilibrium. These include: anger, resentment and frustration related to the violent nature of crime and external factors with one policeman saying that: "We see terrible things ... it makes you angry, you want revenge", while another, commenting on external factors said that "there are so many factors in the system which make it difficult." Urquhart (1996:2) interviewed a policeman who spoke about being angry about crime, while Marks (1995:2) noted that there are many issues in the service such as their salaries which are a source of frustration.

Beliefs about and occurrences in personal and professional relationships also contribute to these emotions. One respondent experienced these feelings towards fellow colleagues saying, "I work in a place where nobody feels nothing for me, so why should I care about them". Another appeared angry and resentful towards members whom he perceived as "lazy" saying, "So die bietjie wat nou hulle bes probeer doen, kry dat hulle ander probeer sleep". Issues and allegations of corruption also contribute to feelings of hatred and suspicion evidenced by the following: "These things (allegations of corruption) ... create hatred and suspicion among the members". Marks (1995:5) states that these emotions are real and are experienced by both black and white police officers, and a study by Syed (1997:11) indicated that corruption has an impact on the general police culture.

Concerning management, anger, frustration and resentment occur due to the lack of acknowledgement, reflected in the following statement: "The police want and want and there is nothing in it for you". Superiors' disrespectful attitude towards lower-ranking officers also contribute to these feelings, as evidenced by the following: "people in the charge office are undermined", while the perception that some superiors are under-qualified also contribute to these feelings, evidenced by the following: "He doesn't have the necessary experience to tell me what to do". Marks (1995:6) wrote about the little or no acknowledgement received by policemen from the superiors. The researcher's personal field notes also reflect the disrespectful attitude of some superiors.

Anger, frustration and resentment are also experienced in the relationship with the community who is viewed as disrespectful towards the policemen, not taking responsibility for themselves or crime and abusing the constitutional bill of rights. This was described as follows: "You end up being beaten by a member of the public", while another stated that "They just fold their arms, and accuse us of everything we are doing". A need was identified for education concerning human rights, with one policeman saying: “... some think it is their right to do anything". The community is also perceived as unreliable and colluding with the perpetrators of crime reporting that: "... it is a battle to get information". Mistry (1997:40) mentions that the old style of policing did not facilitate transparency between the community and police, resulting in a lack of credibility, possibly contributing to the above mentioned feelings. Mention was made about the media, who are perceived in a blaming capacity of only publishing negative stories which generate feelings of anger, frustration and resentment in policemen, evidenced by the following statement: "... even the media, they are all negative ... everybody blames the police". No literature was available to support these findings.

Finally, anger is experienced in personal relationships due to differences between support given and that needed by policemen, contributing to a feeling of being misunderstood: "... they don't understand us, then you become angry". No literature was available to support this. Extensive use of defence mechanisms were made by policemen who participated in this study to cope with these and other emotions and to maintain emotional equilibrium.

Concerning the emotions discussed above, use was made of rationalisation and intellectualisation, where attention is paid to external reality to avoid expression of inner feelings (Kaplan, Sadock \& Grebb, 1994:251). The following statement illustrates this: "Somebody has to do the job". Others made use of displacement, defined by Perko and Kreigh (1988:119) as a mechanism of substitution and redirection which allows the individual to discharge pent-up emotions feelings towards a less threatening target. One participant described this as follows: "I do martial arts - beat people up for fun". Passive aggression towards others is expressed indirectly through passivity, masochism or turning against the self (Kaplan, Sadock \& Grebb, 1994:251) and occurred in this theme as seen in the following statement: "... so I sit in my office all day (laughs) go slow (laughs) ..."

Fear is also experienced due to the nature of police work and this creates a need for self-protection, illustrated by the following : "Jy moet altyd agter jou kyk". Fear is also experienced by policemen who use taxis as a form of transport. One participant reported that: "Once you get into a taxi ... they might find out you are a cop ... they just kill for your firearm or for the sake of being a cop". These attacks on policemen have been widely published with headlines such as "Open season on cops" (Krost, 1997:12). Trauma therefore shatters another personal belief of "it won't happen to me" (Hamber \& Lewis, 1997:9), creating a state of hypervigilance (Shay, 1996:49), where these feelings of fear persist into the homes of policemen: "Not even in my own house can I relax totally". Thus trauma also leaves an individual with a chronic feeling of being on edge (Shay, 1996:49).

Policemen fear for the safety and well-being of their family members in the event of the death of the policemen. One policeman described this as follows: "I'm over-protective of my kids... I don't know if I'm going to see them again". No literature was available to validate this.

Defence mechanisms used against fear include rationalisation: "The area is a higher risk for you than for me because I'm aware" and humour, which is viewed as a mature defence which permits overt expression of feelings and thoughts without personal discomfort or an unpleasant effect on others (Kaplan; Sadock, \& Grebb, 1994:251). The following statement illustrates this: "...today is a competition at Kentucky-shoot a policeman and win a Toyota".

In situations where policemen perceive to have experienced loss, they experience feelings of pain and sadness. One participant spoke of the death of a colleague: "Toe hulle Peter* van my af gevat het, het ek seker die helfde van sy brein in my hande. My beste, beste vriend, dit maak seer". (*Not his real name). An article published in a police journal quoted a member who had lost a colleague as saying, "every time a policeman dies, bits of us die too" (Anon., 1995:20). Personal loss is also incurred when taking the life of another person in the line of duty with one policeman saying: "Maybe every time you lose a bit of yourself". No literature was available to support this. 
In serving the community, policemen are often confronted with devastating scenes resulting in feelings of pain and sadness which may be in conflict with expectations of their external world. One respondent described his experience of this: "We had to follow up on a juvenile ... we came to a shack ... it was very sad... I was confronted by court procedure to arrest the person". Green (1997:14) said that they (policemen) can't help sympathising with the youngster who steals a loaf of bread. Pain and sadness are also experienced due to the disintegration of personal relationships, evidenced by the statement: "Dit maak seer, ek het my familie verloor". No literature was available to validate this.

policemen rationalised and intellectualised these feelings with one quoted as saying: "Naderhand het ek myself getroos dat dit nie iemand is wat ek ken nie" . Dissociation was also used as a mechanism where emotional significance is separated from an idea, object or relationship (Perko \& Kreigh, 1988:119). This is illustrated by the following: "he opened the door for him and shot him three times in the heart and he died on the scene".

Guilt is also experienced when a policeman takes the life of another human being while on duty and is highlighted by the statement: "Ek skiet, ek skiet hom dood ... hy is " $n$ kind, wat sê jy vir sy ma?" An article entitled: "Ek het "n kind geskiet - "n polisieman se selfverwyt" (Louw, 1996:20 - 21), echoes this. Feelings of guilt are rationalised with one participant saying: "If someone wants to kill me, he must be prepared to die".

In addition, feelings of powerlessness, hopelessness and disillusionment also pervade due to the persistence of crime and violence, and because of the continuous threat to the policemen's lives. This was described as follows: "I don't have the power to change it ...", while another reflecting on the threat on his life says: "Because it's a bullet to the back of the head and you are dead, who said you'll see it coming ...". Shay (1996:48) reported that victims of trauma experience emptiness and hopelessness which did not exist prior to the trauma. Secondary repression was used as a mechanism that excludes from awareness what was once experienced as a conscious level (Kaplan, Saddock \& Grebb, 1994:252). This is illustrated by the following: "It doesn't bother me, you become numb, you feel nothing".

Finally, due to isolating behaviour in relationships, the policemen experience feelings of loneliness, highlighted by the following: "Ek bly weg van mense af, somtyds is ek baie eensaam". No literature was available to validate this. Denial and rationalisation are used and one participant said that: "I don't need friends, I've got millions of books, they are my friends... and I've got my gun".

Personal conclusions made, reflect on the story told in this research as being one of "more of the same", where some policemen come from families where relationships are characterised by abuse and enter into a system which has previously also been termed as abusive. Thus, the notion of the perpetrator having previously been a victim has a history dating back to childhood experiences.

\section{CONCLUSIONS}

This research highlighted the emotional, physical and spiritual plight of the policemen and the necessity for the advanced psychiatric nurse practitioner and other health professionals to invest in members of the South African Police Service to facilitate healing of the policemen. In turn this will have a ripple effect on their families and ultimately on the community at large.

\section{LIMITATIONS}

The limitations experienced by the researcher were feelings of fear for personal safety as a result of the area in which this research was carried out. Secondly, difficulty was experienced in finding a conducive venue in which to conduct interviews.

\section{RECOMMENDATIONS}

Recommendations of this research were made with specific reference to nursing practice, education and research.

\section{Nursing Practice}

It is clear from the research results that the policemen in South Africa require professional help and support in dealing with their experiences of crime and violence and the impact it has on their lives.

\section{Nursing Education}

The nursing curriculum of all universities and colleges should be reviewed and if not yet done, the exploration of the effects and impact that crime and violence has on the entire South African population should be incorporated. Nurses should be encouraged to actively participate in the combating of crime of any nature in their professional and personal lives, thus contributing to the reconciliation and nation-building process in the country. They should also be educated in various victim aid programmes ensuring the continuation of stories told by "survivors".

\section{Nursing Research}

Further research needs to be conducted with respect to :

Developing a model for support of single male policemen belonging to one of three identified units working in a specific high-risk metropolitan area in Gauteng and having this model evaluated within nursing practice.

\section{ACKNOWLEDGEMENTS}

I would like to thank Dr Antoinette Gmeiner for her supervision of this study, as well as Dr Sandra van Wyk for the independent coding of the data.

\section{BIBLIOGRAPHY}

ANON, 1996: Safety and order. www.sacs.org.za.80, 11 Aug. 1996:1 - 14

ANON. 1995: A policeman's private hell. Servamus, Nov. 1995:18-20.

ANON. 1993: Stres. Servamus, July 1993: 6-13.

ANON. 1996: Murder, suicide and stress take toll on police. The

Star, 19 March 1996:2.

ANON. 1996: The police. The Citizen, 25 Nov. 1996:12. 
AUGUST, T 1994: Focus on cop killers. The Sowetan, 17 Aug. 1994:8.

BURNS, N \& GROVE, SK 1993: The practice of nursing research : Conduct, critique and utilisation. Philadelphia: WG Saunders.

CRESSWELL, JW 1994: Research design : qualitative and quantitative approaches. California, London, New Delhi: Sage Publications.

ENSOR, L 1996: SA is heading for the abyss, warns De Klerk. Business Day, 27 Nov. 1996:2.

FRIEDMAN, R 1996: Police hi on tech, low on cash. The Sunday Times, 26 Nov. 1996:4

GREEN, P 1997: It is not foolscap pads that the police need to beat crime. The Star, 3 Aug. 1997:14.

HAMBER, B \& LEWIS, S 1997: An overview of the consequences of violence and trauma in South Africa. Braamfontein: Centre for the Study of Violence and Reconciliation.

HUISAMEN, M 1993: "Ek kan nie meer nie ...". Servamus, Oct. 1993:18 - 19.

KAPLAN, HI; SADOCK, BJ AND GREBB, JA 1994: Synopsis of psychiatry : Behavioural sciences : Clinical psychiatry; seventh edition. Baltimore: Williams and Wilkens.

KREFTING, L 1991: Rigor in qualitative research: the assessment of trustworthiness. The American Journal of Occupational Therapy, 45(3) March. 1991:214-222.

KROST, P 1997: Open season on killing cops who are doing their jobs. The Star, 12 April 1997:12.

KRUGER, G 1996: SAPD - stres: "n kultuur teen sielkunde kwel. Die Beeld, 30 Jan. 1996:11.

LEVIN, N; NGUBENI, K \& SIMPSON, G 1994: Meeting the challenge of change? Notes on policing and transition in South Africa. Braamfontein: Centre for the Study of Violence and Reconciliation.

LOUW, E 1996: "Ek het 'n kind geskiet." Huisgenoot, April 1996:20-21.

MARAIS, E \& RAUCH, J 1994: Reform and prospects. Braamfontein: Centre for the Study of Violence and Reconciliation. MARKS, M 1995: Stresses in the South African Police Service. Braamfontein: Centre for the Study of Violence and Reconciliation. MISTRY, D 1997: A review of community policing. Braamfontein: Centre for the Study of Violence and Reconciliation.

MOUTON, J \& MARAIS, HC 1994: Basic concepts in the methodology of the social sciences. Pretoria: HSRC Publishers.

PERKO, JE \& KREIGH, HZ 1988: Psychiatric and Mental Health Nursing; third edition. Connecticut: Appleton and Langa.

POGGENPOEL, M \& MULLER, M 1996: Challenges facing the South African Nursing profession. Health SA Gesondheid Interdisciplinary Research Journal, 1(1), March 1996:9 - 14.

REEVES, J 1997: Street survey wises up on crime stats. Saturday Star, 4 October 1997:13.

SHAY, J 1996: Shattered lives. Family therapy networker. July 1996:46- 54

SOUTH AFRICAN BROADCASTING ASSOCIATION, 1996:

Good cop bad cop.

SOUTH AFRICAN PRESS ASSOCIATION, 1997: JHB suburbs short of 1753 policeman. The Star, 8 May 1997:7.

SOUTH AFRICAN PRESS ASSOCIATION, 1997: Negative image source of stress says report. The Star, 13 Jan. 1997:9.

SYED, T 1997: Not Victimless: Understanding the harmful effect of police corruption. Braamfontein: Centre for the Study of Violence and Reconciliation.

URQUHART, C 1996: Cops strike back in city crime war. The Star, 26 Oct. 1996:2.

\section{POST-DOKTORALE FORUM \\ VAN DIE DEPARTEMENT VERPLEEGKUNDE}

Die Departement Verpleegkunde het op 8 Mei 1998 die eerste jaarlikse Post-doktorale Forum gehou. Die idee vir die forum het ontstaan toe Proff. Muller en Botes aan ' $n$ soortgelyke forum deelgeneem het tydens hul besoek aan Kanada in 1997.

Die forum was deur Prof. Jennifer Sleep van die Thames Valley University van Brittanje toegespreek oor die onderwerp "Randomized clinical trial \& evidence based nursing." Prof. Hennie Lötter van die Departement Filosofie het ' $n$ bespreking gegee oor "The complexity of science."

In die finale sessie het Prof. Annatjie Botes van die Departement Verpleegkunde ' $n$ werkswinkel gelei waar die evaluasie van navorsingsverslae en -artikels bespreek is.

Die forum is bygewoon deur kollegas met doktorsgrade en kollegas wat tans besig is met hulle doktorsgrade. Instansies landwyd was verteenwoordig. 